\title{
You Can't Write Without Research: The Role of Research INSTRUCTION IN THE UPPER-LEVEL WRITING REQUIREMENT
}

\author{
Alyson M. Drake*
}

\section{INTRODUCTION}

Scholarly writing has been a mainstay in the law school curriculum for decades. ${ }^{1}$ Students are often expected to complete a scholarly research paper for seminar classes, independent research assignments, and law journal notes. ${ }^{2}$ Despite recent strides to incorporate more practice-focused writing into the law school curriculum, ${ }^{3}$ the fact still remains that the majority of students meet the upper-level writing requirement by preparing and submitting a piece of scholarly writing. ${ }^{4}$ Furthermore, this is unlikely to change due to the costs associated with hiring new legal writing faculty or adjuncts to

* Director of the Excellence in Legal Research Program and adjunct professor, Texas Tech University School of Law. Many thanks to Jamie Baker for multiple helpful discussions during the drafting of this Article. Thanks also to Taryn Rucinzki and Heather Simmons for reviewing an early draft of the Article and offering valuable feedback. I am also thankful to Martha Posey for her excellent research assistance. This work was made possible by the support of the Texas Tech University School of Law and the Texas Tech Women's Writing Group.

1 See generally Elizabeth Fajans \& MARY R. FALK, SCHOlarly Writing FOR LAW STUdENTS: SEMINAR PAPERS, LAW REVIEW NOTES AND LAW REVIEW COMPETITION PAPERS 2 (4th ed. 2011) (discussing how the most common form of scholarly writing, law review journals, has been around for centuries).

2 Id.

3 See, e.g., Kenneth D. Chestek, MacCrate (in)Action: The Case for Enhancing the Upper-Level Writing Requirement in Law Schools, 78 U. COLO. L. REV. 115, 116 (2007) (suggesting that law students would be better served by engaging in writing that mirrors more closely what they will do in practice). But see, e.g., Kristina V. Foehrkolb \& Marc A. DeSimone, Jr., Debunking the Myths Surrounding Student Scholarly Writing, 74 MD. L. REV. 169, 170 (2014) ("Law schools, and in turn faculty, should promote scholarly writing by law students because it engages cognitive processes and problem-solving skills which are not implicated by other elements of the standard legal writing curriculum.").

4 See infra Part II.A. 
teach smaller sections of practice-focused writing courses. ${ }^{5}$

As such, the legal academy should turn its focus to improving the upper-level writing experience students are currently having. Currently, most students receive little supervision and feedback over the course of the scholarly research and writing process. ${ }^{6}$ This is particularly problematic because the training that these students receive in the first year is aimed at practice-focused research and writing methods, leaving many students to struggle when faced with a scholarly writing project. $^{7}$ One possible solution to this problem is to include research librarians as part of the upper-level writing requirement. Doing so will provide a cost savings to law schools while lessening the burden on the doctrinal and legal writing faculty in supervising students completing the requirement, improving paper quality, and providing for a better overall experience for students.

Part II of this Article discusses the current American Bar Association ("ABA") standard regarding the upper-level writing requirement and explains how law schools are currently interpreting that standard, particularly in regard to the importance of research in the upper-level writing requirement. ${ }^{8}$ Part III describes the key differences between scholarly legal research and practice-focused research. ${ }^{9}$ Part IV provides arguments on why law librarians should be the ones instructing students in scholarly research. ${ }^{10}$ It also provides the results of a survey on how law librarians across the country are currently instructing students on how to conduct scholarly research. ${ }^{11}$ Part V proposes four ways law librarians can begin filling the scholarly

5 See Chestek, supra note 3, at 139 (explaining the costs of teaching legal writing because of the need for "intensive and frequent contact between teacher and student").

6 See id. at 138-39. This lack of supervision and feedback is not due to a lack of interest or caring on the part of faculty members. $I d$. Rather, with class sizes too large and many demands on their time, some faculty struggle to find time to have sufficient conferences and provide significant feedback to make the scholarly writing process meaningful to the students. Id.

7 See infra Part II.A.

8 See infra Part II.

9 See infra Part III.

10 See infra Part IV.A.

11 See infra Part IV.B. 
research gap. ${ }^{12}$

\section{The AdVAnCed Legal Writing ReQuirement}

\section{A. The Current Standard}

ABA Standard 303(a) sets out the requirements that every law student must meet during the course of their law school experience. ${ }^{13}$ Among other requirements, 303(a) mandates that students have "one writing experience in the first year and at least one additional writing experience after the first year, both of which are faculty supervised."14 In most, if not all, cases, the first-year writing experience is part of a first-year skills course focusing on practice-oriented skills, including research, writing, and analytical thinking. ${ }^{15}$ With the upper-level writing requirement, however, the focus on lawyerly practice shifts to a more scholarly endeavor for most students as they take on a seminar course or a supervised legal research project with a faculty member in which they write an academic paper. ${ }^{16}$

Official Interpretation 303-2 gives further guidance on what is

12 See infra Part V.

13 Am. BAR Ass'N Section of Legal Educ.\& Admissions, ABA STANDARDS AND RULES OF PROCEDURE FOR APPROVAL OF LAW SCHOOLS 2015-2016, § 303(a) (2015) [hereinafter 2015 ABA STANDARDS].

14 Id.

15 See generally Chestek, supra note 3, at 118-19 (discussing the legal skills needed for lawyering and the additional writing requirements after the first year).

16 Some students can fulfill the upper-level writing requirement by completing a skills-focused writing course, such as contract drafting or advanced legal writing. E.g., Cincinnati Law J.D. Degree Requirements, U. CIN., http://www.law.uc.edu/ degree-requirements (last visited Nov. 21, 2016); College of Law Catalog / Student Handbook 2016-2017, U. IDAHO C. LAw, at 33 https://www.uidaho.edu/law/ academics/academic-admin/handbook (last visited Nov. 21, 2016). The requirement of faculty supervision is a change that was made in the most recent revisions to the ABA Standards in August 2014; the standard used to say instructor instead of faculty. Compare ABA STANDARDS, $\S 303$ (a) (requiring that a law student has one writing experience their first year and another after), with AM. BAR ASS'N SECTION OF LEGAL EduC. \& ADMISSIONS, ABA STANDARDS AND RULES FOR PROCEDURE FOR APPROVAL OF LAW SCHOOLS, § 302(a)(3) (2013-2014) [hereinafter 2013-2014 ABA STANDARDS] (requiring that a law student has received substantive instruction in "writing in a legal context, including at least one rigorous writing experience in the first year and at least one additional rigorous writing experience after" (emphasis added)). 
expected of these writing experiences: "Factors to be considered in evaluating the rigor of a writing experience include the number and nature of writing projects assigned to students, the form and extent of individualized assessment of a student's written products, and the number of drafts that a student must produce for any writing experience." 17 The focus on rigor is likely due to the previous version of the standard, which was adapted in August 2014; the earlier standard required that students have "substantial instruction in ... writing in a legal context, including at least one rigorous writing experience... after the first year."18 At a recent faculty meeting, our dean gave further guidance she received from the $\mathrm{ABA}$ managing director, which also focused on rigor: "'Rigor' includes notions of substantiality (although page limits aren't usually called for), analysis (as opposed to purely descriptive work), and it implies research of some sort (not just a thought or opinion piece)."19

It is clear that research is a required element of the advanced legal writing requirement. Unfortunately, the only legal research instruction students have been exposed to at this point in their law school careers has focused solely on how to use research in the practice of law, as opposed to scholarly endeavors. ${ }^{20}$ Most students are unfamiliar with the steps of the scholarly legal research process and do not receive any formalized instruction on scholarly research and writing while fulfilling the advanced legal writing requirement. ${ }^{21}$

\footnotetext{
172015 ABA STANDARDS, supra note 13 (quoting the Interpretation 303-2).

18 Harriet N. Katz, Fulfilling Skills and Writing Requirements in Externships, 21 CLINICAL L. REV. 53, 54 (2014) (quoting 2013-2014 ABA STANDARDS, § 302(a)(3)).

19 Texas Tech University Law School Faculty Meeting Agenda Addendum (Mar. 2016) (on file with author).

20 See Chestek, supra note 3, at 117-18.

21 See Eric B. Easton et Al., SOURCebook on Legal Writing Programs 194 (ABA, 2d ed. 2006) ("Too often, the supervisor provides no feedback to the student, but merely accepts the work and issues a grade. And even where feedback is given, the professor often focuses only on the substance of the paper and provides no instruction or feedback to the student on research and writing.").
} 


\section{B. Law School Interpretations of the Standard}

\section{The Goals and Purposes of the Upper-Level Writing Requirement}

The ABA does not expressly state the purpose of including an upper-level writing requirement in its standards, ${ }^{22}$ but many schools have filled in the gap and described the rationale for having students complete the upper-level writing requirement. ${ }^{23}$ These reasons can be as simple as "ensur[ing] that prior to graduation each student shall have a demonstrated competency in legal research and writing" ${ }^{24}$ to providing an elaborate list of competencies the school hopes its students will gain by completing the requirement. ${ }^{25}$ For example, the University of Akron Law School hopes its upper-level writing requirement will develop the following skills: "(1) thoroughness of research; (2) accuracy in the citation of sources and compliance with formal requirements; (3) a high level of prose composition; (4) understanding of the ideas and theories appearing in the research materials; and (5) creative intellectual effort in the form of analysis, organization, and argument using the research materials." 26

22 However, it seems to be, at least in part, a response to the MacCrate Report's call for more focus on skills-based education. See Chestek, supra note 3, at 122-23 ("[T]he 2001 amendment to the Standards was part of a continuing effort by the ABA to require law schools to focus more on the practical aspects of practicing law and to reduce the perceived 'gap' between academia and the practicing bar."). This may be the reason that some educators advocate for the advanced legal writing requirement to focus on practice-centric writing skills. See, e.g., id. at 116.

23 Id. at 123-24.

24 Am. Univ. Wash. C. Law, Upper-Level Writing Requirement Policy STATEMENT 1 (2017), https://www.wcl.american.edu/registrar/documents/upper_level _writing 2017.pdf.

25 See, e.g., Mitchell Hamline Sch. of LaW Student Handbook, Chapter 3: ACAD. Rules, POlicies AND Procedures 2 (2016), http://mitchellhamline.edu/ students/wp-content/uploads/sites/9/2011/08/Chapter-Three-Sec-2-Curriculum-

Requirements.pdf [hereinafter MITCHELL HAMLINE SCH. OF LAW] (listing "(1) [1] egal [r] esearch; (2) [f]act [i]nvestigation; (3) [w]riting, including organization, grammar, and style; (4); [s] trong personal work ethic and time management; and (5) [c]reative problem solving" as the competencies that the advanced legal writing requirement is meant to instill).

26 UNIV. AKRON SCH. LAW, 9200:610 GENERAL WRITING REQUIREMENT (GWR) STANDARD REQUIREMENTS 1 (2011), https://www.uakron.edu/law/docs/GWRInfo PacketRevised4-1-11.pdf. 
According to the University of California, Berkeley, the writing requirement is 'intended to foster students' intellectual growth and professional development. It should build critical research and writing skills, including the ability to formulate a thesis, to frame a discussion or argument; to find, evaluate, and synthesize relevant materials; and to critically self-evaluate, edit, and revise writing."27

Interestingly, some of the descriptions regarding the goals of the upper-level writing requirement neglect to mention research at all, focusing almost solely on writing. ${ }^{28}$ Other schools describe the need to "research a complex issue," 29 to conduct "careful and competent research,"30 or to do "significant research"31 as important goals of engaging in an upper-level writing requirement course or project, without defining any of these objectives. ${ }^{32}$ Finally, some schools

27 Academic Rules, U.C., https://www.law.berkeley.edu/academics/registrar/ academic-rules/ (last visited July 17, 2016).

28 See, e.g., Fla. COASTAL SCH. LAw, STUdENT HANDBOOK 48 (2016), hittp://www. fcsl.edu/files/Documents/StudentHandbook/Student-Handbook-3-29-16.pdf ("The purpose of the Advanced Legal Writing Requirement (ALWR) is to provide students with a rigorous upper level writing experience that will enhance a student's writing skills in a legal context. ALWR writing projects are designed to challenge a student's organizational, problem-solving and writing abilities. ALWR writing projects are intended to integrate theory and application, provide an opportunity to implement lawyering skills, and/or provide a basis for advocating a particular position."); Student Bulletin-Juris Doctor Program of Study, SANTA ClaRA LAw, http://law.scu.edu/ bulletin/juris-doctor-program-of-study/ (last visited July 17, 2016) ("The ability to write effectively and persuasively is fundamental to law practice. A lawyer's service to society and professional satisfaction depends on an ability to communicate through writing. The purpose of this requirement is (1) to integrate the student's legal knowledge by applying it to a complex problem with original analysis; (2) to deepen the student's writing skills through a systematic process of drafting and redrafting, with the benefit of expert feedback; and (3) to model mentoring relationships, in an applied context, that facilitate lifelong professional learning.").

29 Univ. Ill. C. LAw, ACAD. POLICY HANDBOOK: JURIS DoCTOR STUdENTS 6 (20162017), https://law.illinois.edu/wp-content/uploads/2016/06/Academic-Policy-Hand book-JD-1617-2.pdf.

30 What's What Law Student Handbook, LEWIS \& CLARK L. SCH., http://law.lclark. edu/academics/whats_what/graduation_requirements/fall_2014_or_Later/ (last visited July 17, 2016).

31 Graduation Requirements, PITTLAw, http://law.pitt.edu/resources/graduation/ requirements (last visited July 17, 2016).

32 See generally id. (explaining to students that an upper-level writing requirement is 
describe the need for students to have deep engagement with a legal issue,$^{33}$ which implies the need to do extensive legal research on their paper topic.

\section{Upper-Level Writing Requirements}

Some law schools place stringent requirements on the upperlevel writing requirement, in everything from the number of pages required $^{34}$ to the level of faculty-student interaction required during the writing process. ${ }^{35}$ Most crucially, the level of supervision and feedback seems to vary greatly. ${ }^{36}$ While some schools do not provide a set of criteria for faculty-student interactions in their online descriptions, others put an emphasis on the students' interaction with the faculty. ${ }^{37}$

necessary yet not informing students of the specific writing courses needed to fulfill the graduation requirement).

33 Ind. Univ. MCKInNey SCH. Law, Student Handbook, PART I: ACAd. Rules AND REQUIREMENTS 2 (2016) http://mckinneylaw.iu.edu/students/_docs/handbook/ partl.pdf ("The [Advanced Research and Writing Requirement] is intended to be a capstone experience that enables each student to engage a legal issue to a greater extent than is possible in other course settings.").

34 See, e.g., Graduation Requirements: Advanced Writing Requirement, U. MD. FRANCIS KING CAREY SCH. L., http://www.law.umaryland.edu/academics/program/ curriculum/requirements/writing.html (last updated Mar. 7, 2013) (noting that a paper of twenty-five to thirty pages is "unlikely to meet the requirement"); Academic Matters, U. Mo. SCH. L., http://law.missouri.edu/faq/academic/ (last visited July 17, 2016) (requiring "at least 20 pages"); Graduation Writing Requirement Standards, U. OKLA. C. L., http://www.law.ou.edu/content/writing-requirement-1 (last visited July 17, 2016) ("As a general guideline, the paper should total a minimum of twenty double-spaced textual pages, exclusive of the title page, table of contents, footnotes, bibliography, and appendices."); ST. THOMAS UNIV. SCH. LAW, STUDENT HANDBOOK 2015-2016, 5 (2015-2016), http://www.stu.edu/Portals/law/docs/students/2015-Stu dent-Handbook.pdf ("It is difficult to establish exact quantitative standards but most papers will be at least thirty (30) pages in length with at least seventy (70) citations.").

35 See, e.g., Graduation Requirements: Advanced Writing Requirement, supra note 34.

36 See, e.g., JD Degree Requirements, PENN LAW, https://www.law.upenn.edu/ academics/jd-requirements.php (last visited July 17, 2016); BELMONT UNIV. C. LAW, STUDENT HANDBOOK, 2015-16 ACADEMIC YEAR 30 (2015), http://www.belmont.edu /law/pdf/studenthandbook.pdf; SENIOR RESEARCH GUDELINES, NE. L., http://www. law.northwestern.edu/academics/curricular-offerings/senior-research/documents/Senio rResearchGuidelines.pdf.

37 See, e.g., JD Degree Requirements, supra note 36 (“A senior writing project 
Some schools require at least one conference with the faculty member and student during the course of the writing process; ${ }^{38}$ others do not necessitate any face-to-face interactions, allowing for the faculty member's feedback to be given in a variety of ways. ${ }^{39}$

Some schools provide a detailed set of requirements outlining the writing process. ${ }^{40}$ For example, Vermont Law School suggests that each project "require, in addition to the final draft, at least one detailed outline and one preliminary draft, or two preliminary drafts of the final product," all of which should be reviewed and commented upon by the supervising faculty member. ${ }^{41}$ Mitchell Hamline requires that the paper be written in the following stages: "outline; research plan; partial first draft covering one or two parts of the paper; full draft of all elements of the paper; second full draft of all elements; final paper." ${ }^{.42}$ Each of these stages should receive "significant feedback from their faculty supervisors." 43

should provide faculty-student intellectual interchange and an opportunity for constructive faculty criticism regarding avenues of research, analysis, organization, and style." (emphasis added)). Penn's description notes that "It is expected that the faculty member . . . will provide close personal supervision and comment." Id. See also VERMONT LAW SCH., 2015-16 STUDENT HANDBOOK 32 (2015), http://wwwassets.vermontlaw.edu/Assets/registrar/Student-Handbook-2015-2016.pdf ("Close interaction between student and instructor is considered essential to the success of this requirement.").

38 See, e.g., BELMONT UNIV. C. LAW, supra note 36 (requiring at least one conference before the draft is due). One school, Northwestern University, requires at least twelve meetings to discuss student progress during the writing process if meeting the academic writing requirement through the senior research option. SENIOR RESEARCH GUIDELINES, supra note 36.

39 See, e.g., Academic Rules, CATHOLIC U. AM. COLumbus SCH. L., http://www.law. edu/Announcements/2015-2016/AcademicRules.cfm\#12jd (last visited July 17, 2016) (noting that faculty can give feedback on drafts "in the form of written comments, regular conferences, or both"); PACE LAW SCH., ACAD. RULES AND REGULATIONS 12 (2016), http://www.law.pace.edu/sites/default/files/academics/AcademicRegulations. pdf (allowing for the required feedback to be given "in any combination of the following forms: oral, written, checklists, audiotapes").

40 VERMONT LAW SCHOOL, supra note 37, at 32-33.

41 Id. at 32.

42 MitChell Hamline SCH. OF LAW, supra note 25, at 3-4.

43 Id. at 4. 
Only a few schools list requirements for the research portion of the writing process in their online descriptions. ${ }^{44}$ This oversight process of students' research generally takes the form of a research $1 \mathrm{og}$, research agenda, research plan, or some combination of those. ${ }^{45}$ For example, Pace Law School recommends that a research agenda and research log be included. ${ }^{46}$ Western State requires that either a research log, a peer or self-critique exercise, or faculty feedback on additional drafts be part of the upper-level writing process, but the decision of which to use is left up to the supervising faculty member. ${ }^{47}$ Suffolk mandates that students submit a research plan to their supervising faculty member detailing the authorities relevant to their selected topic that they plan on reviewing. ${ }^{48}$

\section{Means of Completing the Upper-Level Writing Requirement}

The three most common avenues for completing the upper-level writing requirement continue to be scholarly endeavors: seminar papers of a substantial length, a student note or comment for one of the school's journals that is deemed to be of scholarly quality, or an independent or directed research paper supervised by a member of the law school faculty. ${ }^{49}$ Many schools still accept some combination of these three options exclusively, ${ }^{50}$ while many more allow students to meet the upper-level writing requirement with them, while offering a

\footnotetext{
44 Id. at 2-4.

45 PACE LAW SCH., supra note 39, at 12; Rules and Regulations, SUFFolK U., http:// www.suffolk.edu/law/student-life/rulesandregs.php\#rule2H (last visited July 17, 2016).

46 PACE LAW SCH., supra note 39, at 12.

47 Western STATE C. LAw, STUDENT HANDBOOK 21 (2016), https://www.western .edu/sites/default/files/page/docs/2015-2016_Handbook_WEB_FINAL.pdf.

48 SUFFOLK U., supra note 45.

49 UnIV. LOUISVILlE, STUDENT HANDBOOK 2015-2016 11 (2015), http://louisville. edu/law/student-services/handbooks/archive/student-handbook-2015-16-new.

50 See, e.g., Graduation Requirements, U. ALA. SCH. L., http://www.law.ua.edu/ academics/curriculum/graduation-requirements/ (last visited July 17, 2016) (seminar courses); UC Hastings Coll. Law, Course Catalog 2015-2016, 24 (Jan. 8, 2016), http://www.uchastings.edu/academics/education/catalog/CAT15-16.pdf (seminar or independent study); Juris Doctor (J.D.)-Degree Requirements, UCONN SCH. L., https: //www.law.uconn.edu/admissions/juris-doctor-jd (last visited July 17, 2016) (seminar, independent study, or written work for a journal).
} 
few more options for doing so. ${ }^{51}$ Some of these additional options also allow a piece of scholarly writing to meet the requirement: work as a faculty member's research assistant, ${ }^{52}$ winning submissions for a nationally recognized writing contest, ${ }^{53}$ an accepted piece in an external journal, ${ }^{54}$ completion of a course called Law Journal Writing, ${ }^{55}$ taking a scholarly writing workshop, ${ }^{56}$ or writing papers for an advanced level course that is designated as an upper-level writing course but is not a seminar. ${ }^{57}$

At some schools, however, there are some practice-based writing courses and extracurricular activities that meet the upper-level writing requirement, as well as some skills-focused courses that can meet the writing requirement if they require the students to complete a substantial amount of writing. ${ }^{58}$ These include, but are not limited to, the following:

\section{- Moot Court; ${ }^{59}$}

\section{JD Degree Requirements, supra note 36.}

52 See, e.g., id. (allowing for work as a faculty research assistant to meet the upperlevel writing requirement, as long as students are not monetarily compensated for that work); J.D. Written Work Requirement, HARV. L. SCH., http://hls.harvard.edu/dept/ academics/handbook/rules-relating-to-law-school-studies/requirements-for-the-j-d-deg ree/j-d-written-work-requirement/ (last visited July 5, 2016) ("Work done as a research assistant with an HLS faculty member may, in some circumstances, be used to satisfy [the writing requirement].").

53 See, e.g., WidenER Univ. Delaware LaW SCH., STUdent HANDbook 12 (2015), http://delawarelaw.widener.edu/files/resources/20152016studenthandbookde_.pdf.

54 See, e.g., UNIV. LoUISVILLE, supra note 49.

55 See, e.g., Academic Rules, supra note 27.

56 Legal Writing at Duke Law School, DuKE L., https://law.duke.edu/curriculum/legal writing/ (last visited July 17, 2016).

57 See, e.g., Academic Standard and Related Procedures 2016-2017, UCLA, https:// law.ucla.edu/ /media/Assets/Curriculum/Documents/JD\%20Academic\%20Standards \%20-\%202016-2017\%20FINAL.ashx (last visited Nov. 19, 2016) (comparing an earlier version that states no seminar paper can be used as a writing sample).

58 See generally Required Courses, CHAP. U., http://www.chapman.edu/law/ academic-programs/course-descriptions/required.aspx (last visited Nov. 17, 2016) (discussing the main types of writing courses available to satisfy writing requirements for graduation).

59 See, e.g., id. (noting that moot court briefs will meet the writing requirement if there is faculty supervision during the revision process). 
- clinics; ${ }^{60}$

- externships; ${ }^{61}$

- drafting courses; ${ }^{62}$

- advanced legal writing courses; ${ }^{63}$

- advanced legal research courses; ${ }^{64}$

- advanced legal research and writing courses; ${ }^{65}$

- appellate advocacy courses; ${ }^{66}$

- judicial clerkship courses $;{ }^{67}$ and

- experiential courses. $^{68}$

60 See, e.g., Upper-Class Full Time Curriculum, GEo. L., http://www.law.georgetown .edu/academics/academic-programs/jd-program/full-time-program/upper-class.cfm (last visited July 17, 2016).

61 See, e.g., Required Courses, supra note 58 (noting that externship writings can meeting the writing requirement at Chapman University if there is faculty supervision during the revision process).

62 Requirements for Graduation, U. CIN. SCH. L., https://www.law.uc.edu/sites/ default/files/Graduation \%20requirements\%20(1)\%20-\%20rev.\%2007\%2022\%202016 .pdf (last visited Nov. 17, 2016).

63 See, e.g., Fall 2016 Course Schedule, U. S.C. SCH. L., http://law.sc.edu/about/ search.shtml?cx $=001293925179400817363 \% 3$ Adicyjfb3d5y\&cof=FORID\%3A10\&ie $=\mathrm{UTF}-8 \& \mathrm{q}=$ course + schedule $\&$ sa $=$ SEARCH (last updated Aug. 16, 2016) (follow out to "1. Course Schedules ...." (indicating that advanced legal writing courses meet the writing requirement)).

64 See, e.g., Legal Writing, DePAUL C. L., http://law.depaul.edu/academics/Pages/ legal-writing.aspx (last visited July 17, 2016) ("[A]ll students are required to take an approved upper-level writing course. The curriculum includes courses in legal drafting, advanced legal research[,] and judicial and scholarly writing.").

65 See, e.g., Academic Rules, supra note 27.

66 See, e.g., AleXander Blewett III SCH. LAw, L. Student HandBook 20152016, 34 (2015), http://www.umt.edu/law/academics/students/handbook/.

67 See, e.g., Univ. Det. Mercy Sch. Law, Student HandBooK 11 (2016), http:// www.law.udmercy.edu/students/pdfs/Formatted\%20Handbook\%202016.pdf.

68 See, e.g., Student Bulletin-Juris Doctor Program of Study, supra note 28 ("Students may satisfy the Supervised Analytical Writing Requirement in a variety of ways including ... [a] brief written as part of a[n] . . experiential learning course as 
As schools continue to become more focused on practice-ready skills, ${ }^{69}$ it is likely that allowing practice-based writing courses to meet the upper-level writing requirement will become more common at law schools across the country. Based on surveying the upper-level writing program descriptions on the websites of all the ABA-accredited law schools, it seems that today the majority of students are still meeting the requirement by submitting a piece of scholarly legal writing, which in turns means that those students are engaging in scholarly legal research. ${ }^{70}$

\section{SChOlarly Versus Practice-Oriented Legal Research}

Scholarly and practice-oriented legal research are, on their face, similar. Both assume a general familiarity with the methods and materials of legal research and a basic knowledge of resources and search techniques. ${ }^{71}$ Unfortunately, this base knowledge is not a given with most law students. ${ }^{72}$ Out of all topics included in the first-year curriculum, legal research may receive the most divergent coverage. ${ }^{73}$ What a student learns varies dramatically based on what law school she attends and who her instructor is. ${ }^{74}$ In some first-year skills courses, there is still significant coverage of print materials; at others, the focus is entirely on how to search in electronic subscription databases. ${ }^{75}$ Other differences include the jurisdictions covered-perhaps the curriculum covers primarily federal materials or perhaps it places an emphasis on the jurisdiction in which the law school is located. ${ }^{76}$ Some first year skills courses cover just the basics of statutory and case law research, while others delve into administrative regulations and

long as it satisfies [other] requirements set out ....").

69 Caroline Osborne, The State of Legal Research Education; A Survey of First Year Legal Research Programs or "Why Johnny and Jane Cannot Research" 1-2 (Wash. \& Lee Pub. Legal Res. Paper Series, Working Paper No. 2016-1) (Jan. 29, 2016).

$70 \quad I d$. at 6.

71 Id. at 1, 5-6.

72 Id. at 4-5.

73 Id. at 5-9, 15.

74 Osborne, supra note 69 , at 1, 13-14.

75 Id. at 13-15.

76 Id. 
legislative history. ${ }^{77}$ At some schools, most of the research instruction is left to Westlaw and Lexis representatives, while at others it is taught by legal writing instructors, doctrinal faculty, trained law librarians, or even adjunct practitioners. ${ }^{78}$ The time spent on legal research differs greatly as well. ${ }^{79}$ Some students get a full year of formal legal research instruction, while others get a single semester or even just a few weeks of the basics before they are expected to tackle research on their own. ${ }^{80}$

Even at those schools with a robust legal research program, students may be unprepared to tackle a scholarly legal research project. Their legal research instruction was likely focused on how to conduct legal research when presented with an issue or issues based on a fictional fact pattern produced to mimic a legal issue they might encounter in practice, rather than a larger scope topic that would be addressed in an academic paper. Many students are also not introduced to key resources, such as municipal codes, fifty state surveys, and legislative histories, which can be helpful in writing a scholarly paper. ${ }^{81}$ Lastly, students may not be overly familiar with certain types of secondary sources that will be important in conducting the background information necessary to a scholarly paper. Unfortunately, all of these factors combined means that many students are not adequately prepared to undertake an academic paper, as scholarly legal research differs from practice-oriented legal research in at least four ways. ${ }^{82}$

First, the goals of practice-oriented research and scholarly research differ greatly. ${ }^{83}$ The goal in practice-oriented research is, at its most basic level, to solve the client's problem as quickly and efficiently as possible. ${ }^{84}$ Conversely, the goal of scholarly research is to "develop,

\footnotetext{
77 Id. at $14-16$.

78 Id. at $13-14$.

79 Id. at 8 .

80 Id.

81 Id. at $14-15$.

82 See generally FAJANS \& FALK, supra note 1, at 1-2 (discussing the differences in scholarly legal writing and practice-oriented writing that attorneys use every day in legal practice).

83 Id.

84 ROBIN WELLFORD, LEgal ANALYSIS AND WRITING 1-2 (1st ed., Lexis-Nexis 1997).
} 
document, and support a new and plausible thesis about an aspect of the law." 85

Second, with scholarly legal research, students must come up with a topic of their own choosing, ${ }^{86}$ as opposed to being handed a particular problem to solve based on information received from a client. This means a student must do preliminary research to select a topic; they may read current awareness resources, legal blogs, and other news sources to identify a problem in the law that can be addressed in their paper. ${ }^{87}$ Many law students struggle with the initial task of finding a topic to write on and must be introduced to current awareness resources to help them with their topic selection. ${ }^{88}$ Because current awareness resources are not a normal part of the practice-focused research instruction students receive in their first year, ${ }^{89}$ students can get lost in the scholarly research process before they even begin researching and writing.

Furthermore, it is not enough for students simply to select a topic. They must ensure that their topics are original, meaning that students must know how to do a preemption check on their topic to ensure that another author has not already written a paper making the exact same argument. ${ }^{90}$ To do this, students need to understand that a topic must not be wholly new but that the primary argument they want to make must not have been made before in precisely the same way. ${ }^{91}$ Most students, never having written this type of paper, must also be introduced to the steps of a preemption check. ${ }^{92}$ In many cases, this also involves being introduced to new legal resources such as HeinOnline, LegalTrac, the Index to Legal Periodicals, and, depending

\footnotetext{
85 See FAJANS \& FALK, supra note 1, at 53.

86 Id. at 15.

87 Id. at $15-16$.

$88 \quad I d$. at $17-19$.

89 See generally Osborne, supra note 69, at 14-17 (referencing the results from survey questions targeting what is taught in research classes).

90 Eugene Volokh, ACAdemic Legal Writing 105-06 (5th ed., Foundation Press 2016).

91 Id. at 105-06.

92 Scholarly Research Resources: Preemption Checks \& Setting Up Alters, TEXAS TECH U. SCH. L., http://libguides.law.ttu.edu/c.php?g=511758\&p=3746845 (last updated Aug. 24, 2016).
} 
on a student's topic, multidisciplinary databases such as Ebsco and Proquest. ${ }^{93}$ While scholarly researchers hope that their idea for a topic has not been addressed elsewhere, lawyers researching on behalf of a client hope for the opposite. ${ }^{94}$ The best-case scenario for them is clear precedent on their topic that favors their clients. ${ }^{95}$

Third, scholarly research generally relies more heavily on secondary sources than practice-oriented research, where the attorney is focused on finding precedent that supports his argument to the court. ${ }^{96}$ During the first year research experience, many students fail to grasp the importance of secondary sources, as their instruction focuses on finding primary mandatory authority, leaving them inexperienced in using these crucial sources. ${ }^{97}$ Scholarly research does not ignore the primary law but uses secondary sources more often because those sources synthesize and summarize the primary law, saving the researcher time. ${ }^{98}$ The scholarly legal researcher also completes a literature review of their topic, ${ }^{99}$ in part to make sure his or her article has not been preempted but also to give them helpful background information on their topic. ${ }^{100}$ This necessitates a thorough review of the secondary sources. ${ }^{101}$ In most cases, students need to be told what sources to look at to complete a thorough literature review. ${ }^{102}$

Finally, as another scholar has noted, even the note taking differs depending on what type of research is being done. ${ }^{103}$ While note taking for both scholarly and practice-oriented research relies on critical thinking, practice-oriented research focuses on identifying rules,

\footnotetext{
93 See id.

94 See WELLFORD, supra note 84, at 9.

95 Id.

96 See SPenCER L. Simons, TEXas Legal ResearCH 47-95 (Carolina Academic Press, 2d ed. 2012).

97 Osborne supra note 69, at 413.

98 Id.

99 See Preemption Checking, Yale L. SCH. LIBRARY, http://library.law.yale.edu/ preemption-checking (last visited Nov. 20, 2016).

100 Id.

101 See generally id. (detailing all of the secondary sources to check for preemption).

102 Id.

103 FAJANS \& FALK, supra note 1, at 59.
} 
applying those rules to the facts of your case, and making distinctions. ${ }^{104}$ In scholarly research, the critical thinking focuses on considering dense ideas found in law review articles, extrapolating what concepts underlie the authors' arguments, and trying to identify what inferences, points of view, and assumptions the author may have or make. ${ }^{105}$ Then, the author must consider and evaluate how the arguments and analysis fit into their own paper. ${ }^{106}$

\section{THe CURRENT ROLE OF RESEARCH IN THE SCHOLARLY Writing CURRICUlum}

\section{A. Why Librarians Should Teach Scholarly Legal Research Skills}

Most scholarly research instruction that takes place is not formalized. ${ }^{107}$ Faculty members supervising a paper or teaching a seminar course tend to focus primarily on the substantive content of the paper, rather than the quality of the research or writing. ${ }^{108}$ Faculty members may spend some time discussing the most important sources related to the paper topic, advising one of their students to look at a particularly helpful source, or even suggesting that a student meet with a reference librarian for a research consult, but there is rarely an indepth discussion of the scholarly research process from topic selection to preemption check to source selection and refinement. ${ }^{109}$ As such, the research instruction students receive during the course of meeting the advanced legal writing requirement is inconsistent at best and nonexistent at worst.

Faculty members, while experts in the substantive content of their field, are not experts in teaching students about the research process. ${ }^{10}$ In fact, they themselves often rely on their colleagues in the law library to assist them with the more difficult research aspects of their own scholarly writing projects, whether that be locating a difficult-

\footnotetext{
104 Id. at 61; WELLFORD, supra note 84, at 17.

105 FAJANS \& FALK, supra note 1, at 56-60.

106 Id. at 60.

107 Id.

108 EASTON ET AL., supra note 21, at 194.

109 Id. at 191.

110 Id. at 194.
} 
to-find source or finding information from outside legal scholarship that will aid their arguments. ${ }^{111}$

For students fulfilling their upper-level writing requirement with a journal note or comment, their primary supervisors are often student note editors or student comment editors. ${ }^{112}$ While these students are often accomplished writers who may have had their own note selected for publication the previous spring, they are still novices in the area of legal research. These students are too early in their legal career to have the subject specialty research expertise necessary to help a new crop of journal students conduct nuanced research, especially when all of those students are writing on varying topics.

Law librarians are the best-suited individuals within the building to help the students conduct scholarly research, whether students are completing their upper-level writing requirement via a seminar paper, an independent study, or a law review note. First, at most law schools, reference librarians are required to have their Juris Doctor in addition to their Masters of Library Science; ${ }^{113}$ this means that they have experience and knowledge in both the law and in research processes. Many law librarians also have substantial experience with practicing law in a particular area and have subject specialties themselves. ${ }^{114}$ While faculty members will always be a valuable resource to students writing scholarly papers as experts on various subject areas, research librarians should be the go-to resource for students during at least three critical parts of the research process: (1) topic selection, (2) preemption check, and (3) location of scholarly resources beyond the sources that students become familiar with in their first year skills course(s). In many cases, law librarians, experienced scholarly writers, and legal educators can also assist students with paper organization, legal analysis, editing, and citation. Furthermore, when librarians have

11 Ruth LeVor, THE UniQue Role OF ACADEMIC LAW LiBraRies 7, http://aallnet. org/sections/all/storage/marketingtoolkit2004/unique-role.pdf.

112 EASTON ET AL., supra note 21 at 196.

113 Education Requirements, AM. Ass'N L. LIBR., http://www.aallnet.org/mm/Careers /lawlibrarycareers/Education-Requirements, (last visited Sept. 6, 2016).

114 See Law Library Career Information, AM. Ass'N L. LIB, http://www.aallnet.org/ $\mathrm{mm} /$ Careers/lawlibrarycareers/Careers-in-Law-Librarianship.html (last visited Sept. 6, 2016). 
particular specialty areas, they can also be a critical aid in helping students develop their legal arguments.

Topic selection requires staying abreast of the most recent trends and changes in the law. ${ }^{15}$ While most students are at least introduced to some secondary sources in their first year skills class, the focus is definitely on primary sources. ${ }^{116}$ Furthermore, when secondary sources are discussed, the emphasis is usually on books and journal articles, rather than legal news sources and law blogs that will be the most up-todate on current legal issues. ${ }^{117}$ Law librarians are well suited to showing students these resources and explaining how they can be useful to topic selection. ${ }^{18}$ Informally, many law librarians fill this function for law students already; when invited, many law librarians visit seminar courses or new journal member orientations and instruct students on these types of resources. ${ }^{119}$

Preemption checks are a critical part of the scholarly research process. ${ }^{120}$ In most cases, to meet the upper-level writing requirement, a student's work must be original. ${ }^{121}$ To ensure that their argument has not been discussed in the same way before, students must be able to

115 Selecting and Developing a Legal Research Topic: Selecting a Topic, U. MELBOURNE (Oct. 18, 2016, 3:31 PM), http://unimelb.libguides.com/research_topic/ selecting_a_topic.

116 See generally, Osborne, supra note 69, at 413 (discussing the greater percentage of teachers that are teaching statutes as opposed to secondary sources).

117 Compare id. (identifying the recommendation by LexisNexis to increase time devoted to teaching statutory research and administrative law), with JESSICA L. CLARK \& Kristen E. MURRAY, SCHOlaRLY WRITING: IDEAS, EXAMPLES, AND EXECUTION 27, 30-34 (2012) (referencing the different secondary resources to review: treatises, journals, topical and current news articles, and restatements to help brainstorm ideas for scholarly writing).

118 See infra Part IV.B.

119 See infra Part IV.B.

120 VOLOKH, supra note 90, at 106.

121 Student Handbook 2015-2016, ST. ThOMAS U. SCH. L., http://www.stu.edu/Portals /law/docs/students/2015-Student-Handbook.pdf (last visited Nov. 17, 2016). This is certainly true of those students meeting the requirement through writing a journal comment or note but may be less true of those completing seminar papers or an independent research paper, where the importance of having the paper be novel is left up to the individual instructor or advisor. Id. 
complete a full review of the current scholarship. ${ }^{122}$ As mentioned before, the emphasis in the first year program is on cases and statutes, and secondary sources, while mentioned, are not usually discussed at great length. ${ }^{123}$ Furthermore, little time is spent on the advanced searching techniques that might be helpful to do a full literature review. ${ }^{124}$ If students meet with a law librarian about their proposed topic, the librarian can guide them through the process and lead them toward types of sources they did not likely encounter earlier in their legal education. Again, law reviews and journals sometimes request training on preemption checks at new member orientations, so many law librarians already provide this type of training on an as-needed basis. $^{125}$

Once the students have completed the preemption check, they will need guidance on where to begin the scholarly research process for their topic. ${ }^{126}$ While faculty are experts in their niche area, librarians must be fluent in sources in a variety of areas. ${ }^{127}$ Faculty members are able to point students toward a key source in the topical area, but librarians can walk them through a complete research process from secondary sources to primary source materials to public policy materials, statistical information, and nonlegal resources that will bolster their arguments. ${ }^{128}$ This will include showing students how to find lots of types of materials they may need that they are not taught in many first year skills courses. ${ }^{129}$ This can include everything from legislative materials, such as hearings and committee reports, to

122 Organizing Your Social Sciences Research Paper: Writing a Research Proposal, USC LIBR. (Nov. 15, 2016, 9:10AM), http://libguides.usc.edu/writingguide/research proposal.

123 Osborne, supra note 69, at 413.

124 Id. at 418 (comparing the use of statutory research, administrative law, journals, treatises, and other news outlets).

125 See infra Part IV.B.

126 See generally Scholarly Research Resources: Preemption Checks \& Setting Up Alerts, U. TEX. SCH. L. LIBR. LIBGuIDES, http://libguides.law.ttu.edu/c.php?g=511758 $\& \mathrm{p}=3746845$ (last updated Aug. 24, 2016).

127 Sarah E. Ryan \& Teresa M. Miguel-Stearns, The Empirical Research Lat Librarian Part 2: Developing the Role, 24 TRENDS 7, 9 (2014).

128 Id.

129 Id. 
municipal ordinances, and court rules. ${ }^{130}$ Again, librarians hold many one-on-one sessions with students who get stuck and come seeking help with their research, as well as group sessions as they are requested by various members of the law school community. ${ }^{131}$

As legal scholars themselves, librarians are an excellent resource for helping students figure out how to organize a scholarly paper. Many students have never read a full law review article before to know how these articles are structured and, in particular, are unaware of the significant background section that is included. ${ }^{132}$ Students may not know that a legal academic paper requires them to identify a problem and suggest a solution. ${ }^{133}$ Librarians can show students examples of different types of legal articles to help students visualize how to organize their paper and provide them with an outline of the traditional law review article format. ${ }^{134}$ As trained lawyers, librarians can also be a resource for students needing help laying out their legal analysis. ${ }^{135}$ Finally, librarians can be excellent resources for citing those unusual sources that students did not encounter before engaging in their scholarly research. ${ }^{136}$

\section{B. How Librarians are Currently Teaching Scholarly Legal Research}

In thinking about this topic, I began to consider what role law librarians were already taking in instructing students in the area of legal research, citation, and legal writing. Unfortunately, there was no previous literature on what roles law librarians were taking in this area. $^{137}$ As such, in May 2016, I wrote a six-question survey aimed at

\footnotetext{
130 See generally Osborne, supra note 69, at 413 (articulating recommendations on what should be included in law school research curriculum).

131 See infra Part IV.B.

132 FAJANS \& FALK, supra note 1, at 71-73 (providing a basic outline for structuring scholarly writing).

133 VOLOKH, supra note 90, at 10-12.

134 Sid KASKEY, The Law Librarian as a Trainer, 17 LEGAL REFERENCE SERVICES Q.

37,38 (1999).

135 Id.

136 Id.

137 See generally EASTON ET AL., supra note 21, at 156-64 (discussing the evaluation process of legal writing professors from tenure-track faculty, capped faculty, part-time
} 
discovering what types of scholarly legal research instruction were currently taking place at each law school. ${ }^{138}$ The survey was kept short in hopes of having more librarians respond. ${ }^{139}$

The first three questions focused on instruction given to the three groups of students who typically get credit for the advanced legal writing requirement: (1) law review and journal students, (2) students participating in a seminar course, and (3) students completing an independent writing project. ${ }^{140}$ The survey listed common types of instruction done for these groups, as well as an "other" field; respondents were able to select as many types of instruction as they were doing and type in further comments if they wanted to elucidate on their answers. ${ }^{141}$ Question 4 listed other common instructional opportunities that might be offered to students outside of those three groups. ${ }^{142}$ Question 5 asked whether the librarians were offering any other types of scholarly legal research instruction at their law school and gave respondents an opportunity to list what types of instruction. ${ }^{143}$ Question 6 asked whether the respondent knew about anyone else within the law school offering scholarly legal research instruction to the students. ${ }^{144}$

The survey was emailed directly to a designated law librarian at every ABA-accredited law school (198 schools). ${ }^{145}$ I attempted to send the survey to the librarian who seemed to be the head of instruction for the law library at each school, assuming that they would have the most complete picture of all the instruction taking place within the library. ${ }^{146}$

adjuncts, and student instructors but not law librarians).

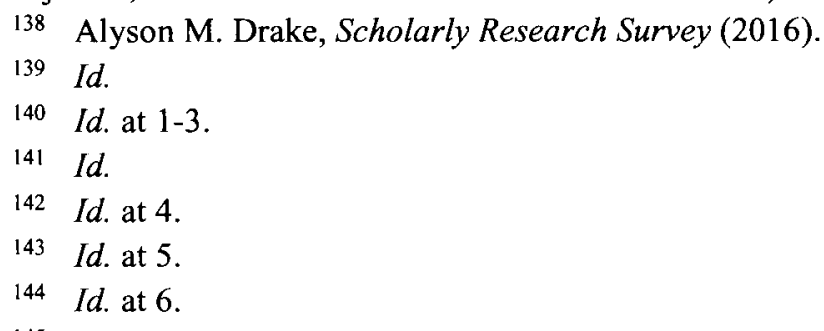

145 ABA-Approved Law Schools, ABA, http://www.americanbar.org/groups/legal_ education/resources/aba_approved_law_schools.html (last visited Dec. 24, 2016). The number of accredited law schools has increased since the survey was conducted. See generally $i d$. (showing that the current number of ABA-accredited law schools is now 205).

146 In some cases, when it was not clear who was in charge of instruction, I sent the 
The email included a link to the survey. The email explained that the survey was only being sent to one librarian per school and asked that one librarian per library complete the survey. The survey did not include identifying information for the librarian or law school; I assumed that librarians would answer more honestly if they did not have to provide identifying information. The survey garnered 126 responses; assuming that no librarians from the same school completed the survey, $63.13 \%$ of the 198 law librarians contacted completed the survey.

Question 1 asks: "Do the librarians at your school offer scholarly legal research instruction to current or prospective journal/law review students on any of the following topics?"147 The types of instruction listed included: (1) note topic selection, (2) preemption checks, (3) the scholarly research process, (4) plagiarism, (5) we do not offer any scholarly research instruction to journals, and (6) other. ${ }^{148}$ Because many law libraries were likely to offer instruction in more than one of the above areas, respondents were able to select multiple responses to this question. ${ }^{149}$ Respondents were also able to provide additional information in the comments field. ${ }^{150}$

survey to the librarian who headed up public services for the library. A few librarians contacted me to let me know that they had sent on the survey to a different librarian within the library or that all the librarians at their school had completed the survey as a team.

147 Drake, supra note 138 , at 1.

148 Id.

149 Id.

$150 \mathrm{Id}$. 


\section{Table 1: Response to Question 1}

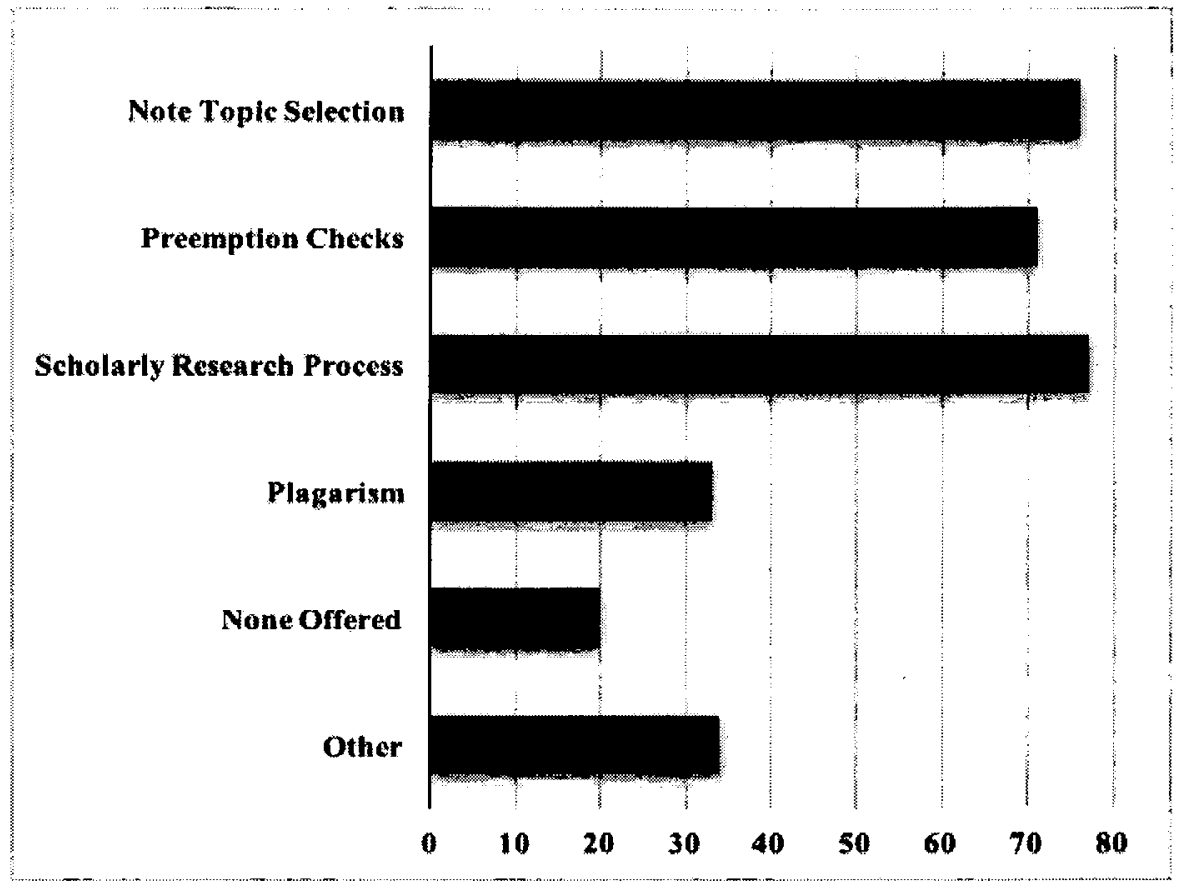

While over half the law libraries reported providing instruction in the areas of note topic selection $(60.32 \%$ or seventy-six schools); preemption checks $(56.35 \%$ or seventy-one schools); and the scholarly research process $(61.11 \%$ or seventy-seven schools), many schools gave additional information in the comments field explaining that these programs were offered irregularly at best, generally only at the request of the law review or journal:

- “On request--haven't had requests for plagiarism."151

- "We offer this to Journals only sometimes-maybe once a year, if they ask for it." 152

- "Research instruction is conducted on an ad hoc basis by reference librarians serving as journal liaisons. There is not a blanket

\footnotetext{
151 Id. at response 115.

$152 \quad I d$. at response 92.
} 
approach for all journals."153

- "We provide instruction when asked to do so by the journal/review. The amount and type of instruction varies by year."154

- "We offer the journals instruction on cite checking and other assistance but they never take us up on our offer."155

In addition to the types of instruction listed, a few libraries reported doing instruction geared toward cite checks, aimed at helping students locate sources cited by authors that students were having trouble locating. ${ }^{156}$ Finally, libraries also reported doing instruction in the areas of citation and Perma.cc. ${ }^{157}$ Several libraries reported having a liaison who would offer services to the journals. ${ }^{158}$ One library reported creating a LibGuide last year, a research guide with information on note selection, preemption checks, and plagiarism, after consulting with the journal editors. ${ }^{159}$ Only twenty libraries, $15.87 \%$ of respondents, reported offering no scholarly legal research instruction to their student-run journals. ${ }^{160}$

Question 2 asks a similar question but aimed at seminar-style courses. ${ }^{161}$ The types of instruction listed mirrored the types listed for instructions to journals. ${ }^{162}$ Again, respondents were able to select multiple answers and to provide additional information in the comments field. ${ }^{163}$

\footnotetext{
153 Id. at response 87.

154 Id. at response 84.

155 Id. at response 4.

156 See generally id. at 1 (commenting that cite checking is offered).

157 Id. at 1.

158 Id.

159 Id. at response 49.

160 Id.

161 "Do the librarians at your school offer scholarly legal research instruction to seminar-style courses on any of the following topics?" (emphasis added).

162 The types of instruction listed included: (1) note topic selection, (2) preemption checks, (3) the scholarly research process, (4) plagiarism, (5) we do not offer any scholarly research instruction to journals, and (6) other. Id.

163 Id. at 2.
} 


\section{Table 2: Response to Question 2}

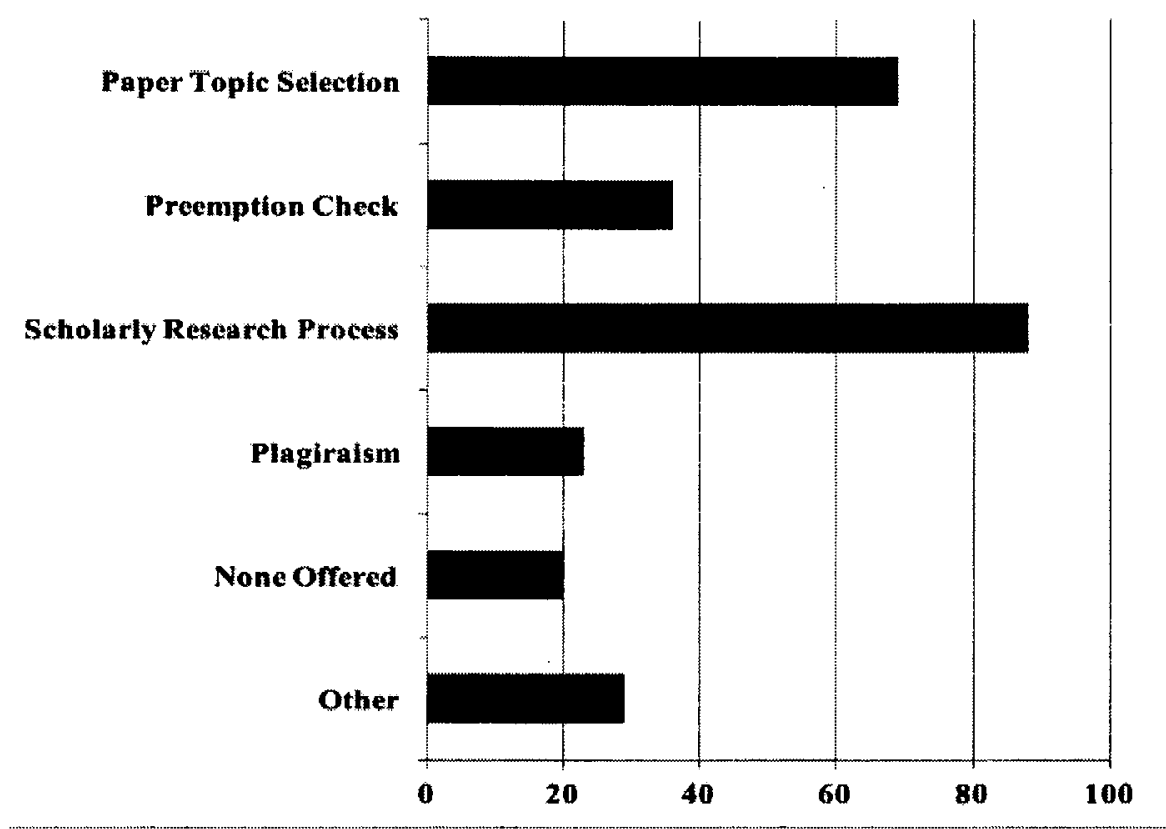

Over half the libraries reported offering scholarly legal research instruction in the areas of paper topic selection $(54.76 \%$ or sixty-nine libraries) and the scholarly research process $(69.84 \%$ or eighty-eight libraries). ${ }^{164}$ Considerably fewer libraries reported offering sessions on conducting a preemption check to seminar classes $(28.857 \%$ or thirtysix law schools, as compared to $56.35 \%$ or seventy-one law schools for law reviews and journals) perhaps suggesting that professors in seminar courses are less interested in completely original arguments than law reviews. ${ }^{165}$ This makes sense, given that the goal of students writing notes or comments for law review is publication, while students writing seminar papers are simply meeting the course requirement and do not necessarily intend to try to have their paper published.

Many libraries again reported that these sessions are held on an inconsistent basis, usually as requested by professors. ${ }^{166}$ One library

164

165

See supra Part V.B.

Id.

Alyson M. Drake, Individual Library Scholarly Research Survey, 79 (2016) 
reported that they "have done this as one-off sessions, [but] are trying to integrate more fully into all seminar courses."167 A few libraries reported teaching seminars themselves, in which they teach all of the topics. ${ }^{168}$ Others reported going into seminar classes but focusing more on locating resources on the topic of the seminar or on conducting interdisciplinary research than any of the topics listed. ${ }^{169}$ Again, only $15.87 \%$ or twenty libraries reported offering no services to law school seminar courses. ${ }^{170}$

Question 3 asks whether librarians at the school offer required scholarly legal research instruction to students engaging in an independent legal research and writing project that counts toward students' advanced legal writing requirement. ${ }^{171}$ The types of instruction listed are the same as those listed for journal students and seminar courses, and respondents were able to select multiple responses and provide additional information in the comments field. ${ }^{172}$

This question was phrased slightly different than the previous two questions because I wanted to discover whether any schools required any mandatory instruction for every student completing the upper-level writing requirement through an independent legal research project. This could be either in the form of a mandatory session for all students completing an independent research paper in a given semester or by requiring that all of those students meet with a librarian the semester they are writing their paper. Instead, most of the respondents seem to have read the question as required for an individual student by the faculty member working with the student on their independent legal research project. ${ }^{173}$

[hereinafter Individual Library Scholarly Research Survey]. Libraries responded that these sessions are "sporadic at best" or "on rare occasions" and that "it varies by semester." Id. at $4,85,91$. One reported that "If a professor requested we speak with their class on these topics, we would, but I cannot recall that happening in the past two years." Id. at 113 .

167 Id. at 68.

$168 I d$. at $16,39,58,66,70,74,82,91,92,96,102-04,118$.

$169 I d$. at $2,12,42,69,112$.

170 Drake, supra note 138 , at 2.

171 Id. at 3.

$172 I d$.

$173 \quad I d$. 


\section{Table 3: Response to Question 3}

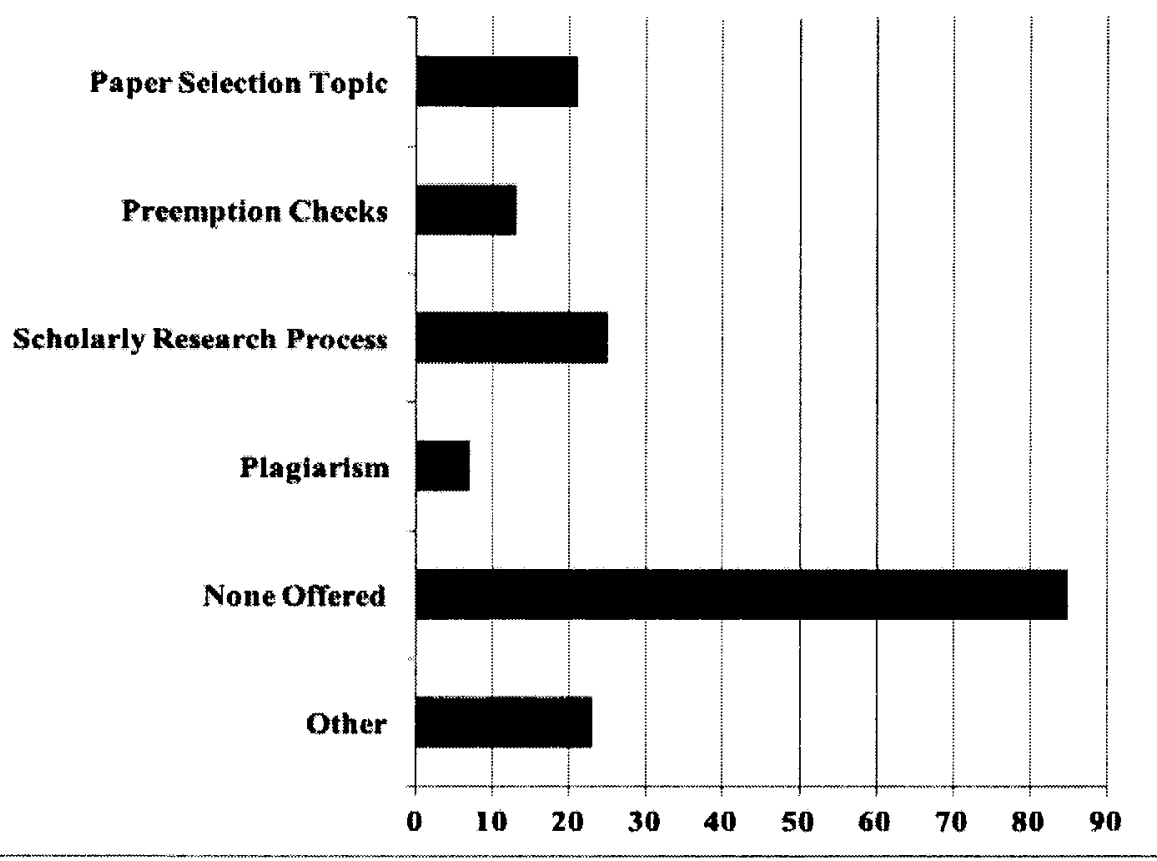

Here, the numbers in every category except "None Offered" decreased dramatically. ${ }^{174}$ Eighty-five schools, or $67.46 \%$, reported that they do not offer required scholarly legal research instruction on any of the topics listed for students who are engaging in an independent study that counts toward the upper-level writing requirement. ${ }^{175}$ While most libraries lacked a formalized, required program for students doing an independent study, many reported working one-on-one with students:

- "We do not offer an[y] of these things in a formal setting, however we do work with independent study students as allowed by their faculty sponsor."176

- “[O]nly if professors specifically request this, we don't do this

174 Id. at 3. The categories were: (1) paper topic selection $16.67 \%$, (2) preemption checks $10.32 \%$, (3) scholarly research process $19.84 \%$, (4) plagiarism $5.56 \%$, (5) none offered $67.46 \%$, and (6) other $18.25 \%$. Id.

175 Id.

176 Individual Library Scholarly Research Survey, supra note 166, at 108. 
routinely." 177

- "All of the above, but nothing formalized so it's rare for librarians to be involved. I personally have supervised an independent study though." 178

- Several schools reported doing one-on-one meetings that were not required but were at the request of the students themselves. ${ }^{179}$ One school reported that "Students who wish to receive credit on an independent study writing project must take a specialized advanced course, Writing for Scholarly Publication, in order to do so. Librarians typically provide a research lecture in this course."180

Question 4 asks: "Do the librarians at your school offer any of the following programs for students?"181 There was an error in how this question was entered into Survey Monkey; unlike the previous questions, it was not set up to allow for multiple responses. ${ }^{182}$ Several respondents reported in the comments that they provide two or more of these types of trainings. ${ }^{183} \mathrm{~A}$ few respondents were also confused about what a "student-librarian liaison program" was and emailed me to ask for clarity on the question. As such, it is likely that the numbers could be higher.

\footnotetext{
177 Id. at 102.

178 Id. at 91.

179 Id. at $79,120$.

180 Id. at 63.

181 Drake, supra note 166 , at 4.

182 Unfortunately, by the time the error was discovered, over eighty respondents had replied to the survey and there was no way to retroactively change it without creating a new survey and sending it back out to all the librarians who had been identified to take the survey. Individual Library Scholarly Research Survey, supra note 166 (showing that the question only allowed for one response).

183 Drake, supra note 138, at 4.
} 
Table 4: Response to Question 4

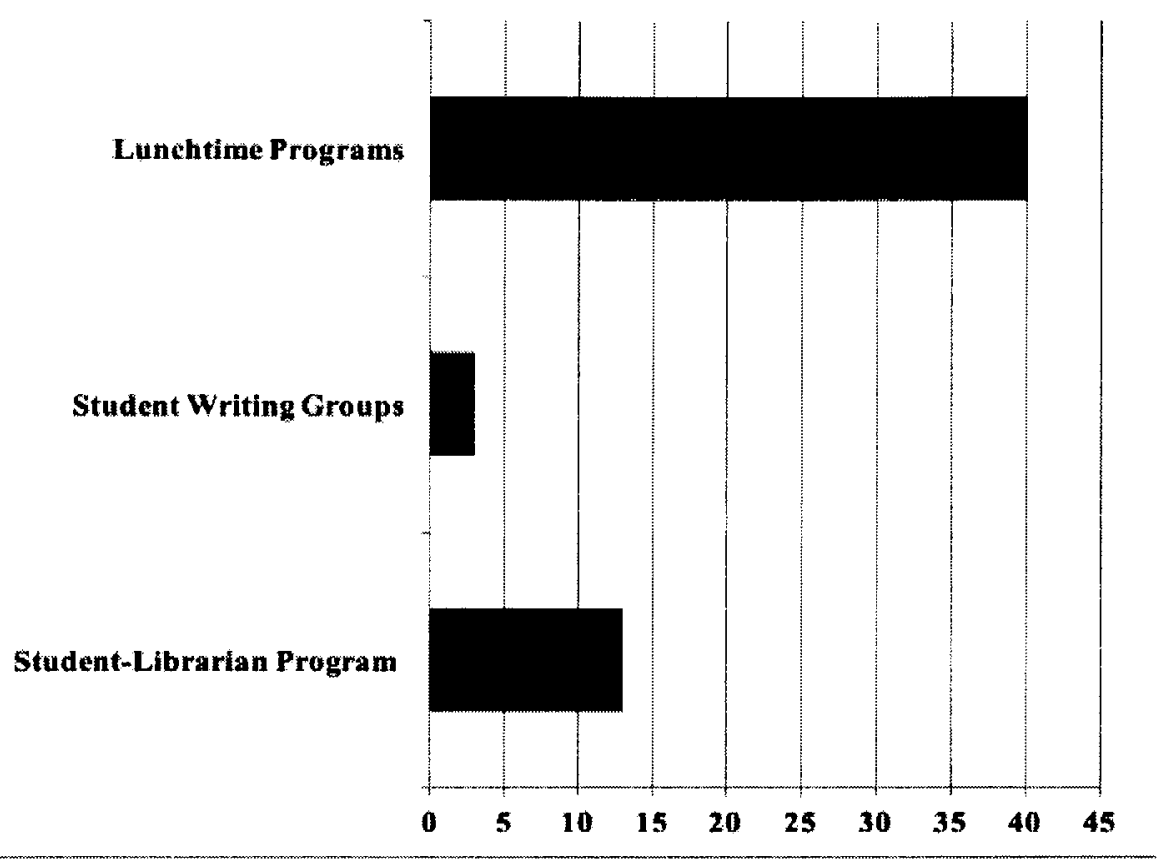

Forty schools, $71.43 \%$, report offering lunchtime programs on conducting scholarly research. ${ }^{184}$ Three schools, $5.36 \%$ of respondents, reported having student writing groups where there is a legal research instruction component. ${ }^{185}$ Thirteen schools, $23.21 \%$ of respondents, reported having a student-librarian liaison program where librarians assist the students with legal research papers that count toward the advanced legal writing requirement. ${ }^{186}$

Question 5 asks: "Do the librarians at your school offer/participate in any other forms of scholarly legal research instruction?"187 Eighty schools responded that they do offer other forms of scholarly legal research instruction. ${ }^{188}$ Responses to this included,

$\begin{array}{ll}184 & \text { Id. } \\ 185 & \text { Id. } \\ 186 & \text { Id. } \\ 187 & \text { Id. at } 5 . \\ 188 & \text { Id. }\end{array}$ 
but were not limited to, the following:

- advanced legal research courses that include components related to scholarly legal research;

- faculty research assistant trainings;

- guest lecturers in nonseminar style classes;

- teaching their own seminar classes, on classes including copyright and legal history, where they cover scholarly research;

- a session on submitting research to ExpressO;

- librarians who teach scholarly writing, which integrates scholarly research and writing;

- required individual meetings with journal students taking scholarly writing course for credit for their work toward journal submission;

- one-on-one instruction with students who stop by to see or make appointments with librarians;

- offering research consultations; and

- $\quad$ a research clinic. ${ }^{189}$

Finally, Question 6 asks: "Are you aware of any research instruction taking place outside of the library to help students meet the advanced legal writing requirement by law school faculty or staff?"190 Ninety-one respondents, $73.39 \%$, reported that they were not aware of any such instruction by law faculty or staff outside the library. ${ }^{191}$ Of the thirty-three libraries who reported that they were aware, answers included but were not limited to:

- scholarly writing courses taught by nonlibrarians that may have a scholarly research component,

- faculty assisting students with independent research papers,

$\begin{array}{ll}189 & I d . \\ 190 & I d . \text { at } 6 . \\ 191 & I d .\end{array}$


- law review and journals teaching members how to conduct basic scholarly research in addition to what the library provides,

- a series of videos on scholarly research and writing that are hosted on The West Education Network ("TWEN") and are required by many seminar professors,

- writing specialist who sometimes provide minimal instruction on topic selection and citation work one-on-one with students,

- $\quad$ preemption check, and

- note topic assistance by Lexis, Westlaw, and Bloomberg vendors. ${ }^{192}$

What is clear from the survey is that many law librarians are already taking steps to guide students through the scholarly legal research process in many and varied ways, just not on a consistent basis or in a structured way. Librarians encounter students who are already frustrated with the process after trying to get started and are hitting a roadblock or who do not know where to begin because they have gotten no guidance at all. The survey also demonstrates that when librarians are asked to instruct in the area of scholarly legal research, they answer the call. The problem is they are not called on regularly enough to make a significant impact on the student body. Coming up with a structured plan for offering these services and showing their value to both the students and faculty is a crucial next step in ensuring that students receive the knowledge they need to make completing the advanced legal writing requirement a worthwhile experience.

\section{STRATEGIES FOR INCORPORATING LIBRARIAN-LED RESEARCH INSTRUCTION INTO THE UPPER-LEVEL WRITING REQUIREMENT}

Based on both the survey responses and my own experiences, there are numerous ways to incorporate necessary scholarly legal research instruction into the upper-level writing requirement. Each strategy centers on law librarians working alongside faculty, supplementing the substantive instruction that students are receiving on their writing projects. ${ }^{193}$ This results in both the students receiving

\footnotetext{
192 Id.

193 See infra Part V.
} 
important instruction to help them write better quality papers-perhaps subsequently improving their chances of publication-and lessens the burden of faculty members with large class sizes or conflicting responsibilities.

\section{A. Weekly Seminar Class for Independent Study Students}

The first avenue for incorporating scholarly legal research instruction would be to require a weekly seminar class for students completing the upper-level writing requirement through an independent or directed research paper. Students would work alongside a faculty member to produce this paper, with differing degrees of oversight. ${ }^{194}$ While some students would likely meet with their supervising professor often over the course of the semester, others would not. ${ }^{195}$ A weekly seminar class covering topics relevant to researching and writing scholarly papers would mean a uniform experience for all students completing the writing requirement through an independent study and making sure that students have guidance throughout the process. Some law schools already offer a class in scholarly research and writing. ${ }^{196}$ In some cases, librarians teach these classes, but it is also possible that a librarian could coteach the class with a writing specialist or a doctrinal faculty member who is interested in the scholarly writing process.

The class could be structured in a few different ways. First, it could be a one-credit class offered once per week over the course of the semester in which the student is meeting the upper-level writing requirement. It could also be offered as a one-credit class twice a week over the first half of the semester because many of the topics that would ideally be offered in such a course-such as topic selection and preemption checks--need to be discussed early in the writing process. The class could also be taken the same semester that the student receives credit for the independent study, for zero credit hours, and simply as a requirement for fulfilling the independent study course. As such, it could simply meet four or five times across the semester, covering a variety of topics. Ideally, the class would be mandatory for

\footnotetext{
194 See supra Part II.B.2.

195 See supra notes 24-26 and accompanying text.

196 See, e.g., 2016-17 Advance Legal Writing Courses Offered By Legal Writing Faculty, U. COLO. BOULDER, http://www.colorado.edu/law/academics/legal-writing (last visited Dec. 24, 2016).
} 
every student completing the independent study for their upper-level writing requirement. Having the class be for credit would demonstrate the importance of research in the scholarly writing process.

Regardless of class structure, there are at least six topics that should be included in the curriculum. The first is topic selection. The instructor would explain what makes a good paper topic and then would demonstrate current awareness resources that will help students find an original topic in an area that is of interest to them. Once a student identifies a topic, the next unit would be the preemption check. The librarian instructor would teach the students how to conduct a preemption check to ensure that students' exact arguments have not before been covered and explain that the preemption check is also a great time to do background research on their topic, as students look at the other literature on the chosen topic.

Next, the librarian would discuss the scholarly research process and how to approach this type of article; students would come up with a research plan for their paper. The fourth topic would be covering the organization of a scholarly article; this would cover different examples of how to structure an article. Editing and proper citation are additional topics that would be covered in such a class. These six classes alone would ensure that students are producing better researched, better organized, and properly attributed writing projects. Depending on the number of students completing an independent study in a particular semester, one-on-one consults with a librarian on their research progress would be an especially beneficial option for this type of course, as each student could get tailored assistance on helpful sources.

\section{B. Research Labs for Seminar Courses}

It is not unusual for instructors to invite librarians into their seminar classes to do a single session on researching the seminar paper topic. ${ }^{197}$ According to the survey, the topic covered most often during these sessions are resources specific to the subject area of the seminar

\footnotetext{
197 Drake, supra note 138 , at 3, 4. Many respondents $(72.41 \%)$ noted that they conducted research seminars as requested. Individual Library Scholarly Research Survey, supra note 166.
} 
course. $^{198}$ Topic selection and the scholarly research process are sometimes covered, but not on a regular basis. ${ }^{199}$ However, preemption checks are only offered at thirty-six schools, $28.57 \%$ of respondents. ${ }^{200}$ As such, seminar instructors are missing out on the opportunity for librarians to instruct in the classroom and for students to produce betterresearched papers. The reason for this is probably that the focus of these seminar classes is the substantive law topic, not on the writing and researching processes. Instructors may not want to give up precious class time to research or writing instruction when there is a considerable amount of content to cover on the topic of the seminar.

One solution is to add a one-credit research workshop onto the seminar class. The ideal structure for this would be a three-hour workshop that meets four to five times over the course of the semester. This would work best with a front-loaded structure, where the class meets several times in the first month of the semester and then tapers off to meet once per month the rest of the semester. The class would be hands on, with the librarian there to assist the students with their research. Ideally, there would be a one-credit research class for each seminar class offered each semester at the law school to ensure that every student has the same research experience over the course of the upper-level writing requirement.

The first session would cover topic selection and preemption. In the first half of this session, the librarian would show current awareness resources related to the topic of the seminar course, and then students would have hands-on time to look for interesting topics for their seminar paper. In the second half of the first session, the librarian would demonstrate how to run a preemption check. In the second session, the librarian instructor would cover the scholarly research process and perhaps have in-class consults with each student. To do so, the students would need to send the instructor a report on their research progress the week before the class, including any questions they have or holes they have discovered in their research, so the librarian can prepare

\footnotetext{
198 Id. at 2.

199 Id. The survey indicated only sixty-nine $(54.76 \%)$ of respondents offered seminars on paper topic selection and only when specifically requested. Individual Library Scholarly Research Survey, supra note 166.

200 Id.
} 
for each session. Alternatively, the librarian could hold one-on-one sessions in her office in lieu of an in-class session.

In the third session, the students would begin outlining the structure of the paper after a discussion about organizing scholarly articles. Sessions four and five could include a hands-on editing session and citation session. These guided working sessions prove valuable to students, as it allows them to make progress over the course of the session after a short lecture on editing or citation. ${ }^{201}$ Having sessions over the course of the semester also ensures that students do not procrastinate until the end of the semester to begin working on their papers. ${ }^{202}$ The librarian teaching the research lab would work with the faculty member teaching the seminar to create a schedule that works with any deadlines the faculty member has for the paper, such as turning in a first draft of the paper.

Having the librarians lead the sessions would lessen the burden on professors teaching the seminars, who may not have the time to meet with every student in a seminar class, of eighteen plus students, at every stage of the paper. Having a research workshop companion class would allow the instructor to meet with the students about the substantive content of the paper, while the librarian instructor can focus on the research, organization, and citation. This should result in better overall papers in the seminar.

Downfalls of this are that it could be very time intensive for the librarians, depending on the number of seminars offered each semester and the number of teaching law librarians at the law school. With the small library faculties at some law schools, it might be difficult to have enough librarians to introduce this kind of program. But, gathering all the students in one classroom is less intensive than meeting with every student meeting the upper-level writing requirement one-on-one.

201 See generally Shailini Jandial George, Teaching the Smartphone Generation: How Cognitive Science Can Improve Learning in Law School, 66 ME. L. REV. 163, 168-70, 186-87 (2013) (focusing on millennials' lack of information retention with just reading and the idea to incorporate hands on learning techniques).

202 See generally Kassandra Barnes, Raymond C. Marateo \& S. Pixy Ferris, Teaching and Learning with the Net Generation, 3 INNOVATE: J. ONLINE EDUC. 1, 2 (2007) (indicating that millennials want deadlines and to receive feedback from professors throughout the semester). 


\section{Student Writing Groups}

A less intensive librarian-led solution for research instruction, for those students completing the upper-level writing requirement, is student-writing groups. While voluntary for students, these groups meet with a librarian over the course of the semester to cover the same topics covered in the course, for students completing the independent study, and in the research lab, for the seminar students.

Law librarians can host the writing groups in the library and plan the topics to coincide with the schedule of law review due dates, seminar due dates, or both, over the course of the year. At the start of both the fall and spring semester, sessions on topic selection and preemption checks would be offered to assist students who are working on a law review, journal note or comment, or those taking a seminar course. Group sessions on conducting scholarly research and how to organize a scholarly research would take place in both semesters. Editing, citation, and write-in sessions would take place toward the end of each semester, as well as at the beginning of the spring semester to coincide with many law review and journal writing schedules.

In August 2016, Texas Tech School of Law created the nation's first Scribes Student Writing Group. ${ }^{203}$ At the inaugural meeting, hosted in the law library's collaborative commons, two library faculty members, along with one doctrinal faculty member, the law school's writing specialist, and the law school's dean, met with eleven students to talk about topic selection. ${ }^{204}$ The students, most of whom were writing either a journal comment or a seminar paper that semester, had a chance to learn about what makes for a good topic and what resources can be helpful in selecting a good topic. ${ }^{205}$ The students who attended

203 Texas Tech University School of Law Joins The John Marshall Law School in Establishing a Pilot Scribes Program for Students, SCRIVENER, 2016, at 10, http:// media.wix.com/ugd/3eec74_cecc040c6322475f816dcea6e6588177.pdf [hereinafter SCRIVENER].

204 See generally George Watson, Scribes Moves National Headquarter to Texas Tech University School of Law, TEXAS TECH U. (July 30, 2015), http://today.ttu.edu/ posts/2015/07/scribes-american-society-of-legal-writers-moves-national-headquartersto-school-of-law (discussing the members of the Texas Tech University staff involved in the Scribes Writing Group).

205 Alyson Drake, Scholarly Research Resources, REPORTER-TEXAS TECH L. LIBR. 
all reported having a good experience, and four of the students who attended scheduled follow-up meetings to further discuss resources for their papers. ${ }^{206}$ Subsequent meetings during the Fall 2016 semester covered a discussion of good writing, editing, and citation; there was also a write-in in the library in October $2016 .^{207}$

Similar to the workshop for the seminar classes, these were primarily working sessions. The librarians gave a short information session on the topic for that session and then the students engaged in the task related to that instruction-searching for a topic, running a preemption check, and more. By participating in multiple sessions, students made continual progress on their paper over the course of the semester. The students also got to know the librarians in a less formal atmosphere, which made them more comfortable in meeting with the librarians outside the writing group. ${ }^{208}$ An additional bonus was that the students were able to connect with other students working on papers, allowing the opportunity for peer editing and other support from their classmates. ${ }^{209}$ The librarians were also able to coordinate others-like doctrinal faculty members and writing specialists - to attend the group and share with the students about their own writing processes, potentially providing writing tips in the process. Several students who attended one or more Scribes events at Texas Tech during the Fall 2016 semester or at least one individualized session with a librarian to discuss their scholarly paper reported receiving high marks on their seminar papers. In addition, multiple journal students who attended a Scribes event or an event plus a follow-up with a librarian had their comments selected for publication in Spring 2017.

(Sept. 7, 2016), https://texastechlawlibrary.wordpress.com/2016/09/07/scholarlyresearch-resources/.

206 Id.

207 SCRIVENER, supra note 203, at 10.

208 The first two sessions of the Scribes Student Writing Group at Texas Tech have resulted in nearly a dozen individual research consults with a librarian outside of the group's regular meeting time.

209 See Cassandra L. Hill, Peer Editing: A Comprehensive Pedagogical Approach to Maximize Assessment Opportunities, Integrate Collaborative Learning, and Achieve Desired Outcomes, 11 NEV. L. J. 667, 671-76 (2011). 


\section{Student-Librarian Liaison Program}

The final recommendation for a librarian-run program, for students completing the upper-level writing requirement, is a studentlibrarian liaison program. According to the survey, at least thirteen schools have a student-librarian liaison program. ${ }^{210}$ In this approach, each student completing the upper-level writing requirement that semester - whether by a seminar paper, an independent study, or a law review note-would be partnered with a librarian. To complete the upper-level writing requirement, the student would have, at a minimum, one mandatory meeting with the librarian to discuss how to do a preemption check of their topic and how to approach the scholarly research process. Requiring a second meeting after the student has conducted most of their research would be ideal, as then the librarian could help the student address gaps in their research.

Obviously, this is a time-intensive program for the librarian. To properly prepare for the meetings, the students would have to contact the librarian prior to the meetings with information on their proposed topic or their research progress, so the librarian could prepare to make the meetings as productive as possible. Depending on the number of students completing the upper-level writing requirement each semester and the number of librarians at the law library, librarians could have dozens of student partners each semester, each writing a paper on very different topics. While very time intensive, students will get more individualized attention in this approach.

Combining these four approaches-independent research project seminar, seminar class research labs, student writing groups, and student-librarian liaison programs - could certainly work to minimize this work. If a course for independent study students and a research lab for seminar students was being offered, only journal students would need to have the student-librarian liaison program; at some schools, librarians are already assigned to journals as liaisons, so this would

\footnotetext{
210 It is not clear whether all of these programs require a meeting between the student and his or her librarian liaison during the course of the upper-level writing requirement. Further research needs to be done on the structure and success of these programs, as well as on the student body size and number of librarians at the schools offering these liaison programs. See Drake, supra note 138, at 4 (2016).
} 
simply be an extension of this program. Alternatively, if there was a student writing group in place for each of the journals and it was made mandatory, then librarians could meet with the journal students as a group rather than one-on-one.

\section{CONCLUSION}

Given the ABA's acknowledgment of research as an important component of the upper-level writing requirement and the fact that the majority of students are still completing the upper-level writing requirement through a scholarly research endeavor, there is a great need for more structured scholarly research instruction in the upper-level writing requirement. ${ }^{211}$ Getting buy in from law school administrations and faculties is the next step in incorporating this type of instruction into the mandatory curriculum for this requirement and ensuring that research instruction is included in every student's fulfillment of the upper-level writing requirement.

There are a few approaches that might be taken. First, law librarians can try making inroads with just one or two faculty members. They can do this by making a concentrated effort to do outreach with faculty members about the possibility of doing research consults with students who are taking a faculty member's seminar course or who are completing an independent research paper. This allows the faculty member to have assistance on these papers without losing class time. Librarians can also offer to come to their class to do a session. These same services can be offered to the law reviews and journals at the law school-individual research consults and instruction at the annual new member orientation. Second, law librarians can reach out directly to the student body, offering research consultations to students. ${ }^{212}$ Lastly, and most importantly, librarians can keep statistics of who they are having research consults with, what is being discussed in those meetings, and how many of those students are then being published. Keeping track of

\footnotetext{
2112015 ABA STANDARDS, supra note 13.

212 These services were offered to the students at Texas Tech the first week of class in 2016, and over the course of the Fall semester, forty-seven students writing a seminar paper, independent research paper, or journal comment that semester scheduled individual research consults with a librarian. Over a dozen of those students scheduled follow-up sessions after their initial consult.
} 
those students also allows librarians to follow up with students about strategies for submitting papers for publication to help bolster those numbers. Having these statistics will be a substantial help when trying to convince the faculty (1) that the students want and need this sort of instruction and (2) that this type of instruction leads to better, more publishable papers.

Better student papers, a less onerous experience for faculty members supervising these papers, and more students being published will follow from allowing librarians to take the lead in offering a uniform, structured program of scholarly legal research instruction to students completing the upper-level writing requirement. 